\title{
Quantitative Measurement of Calcium Flux through Muscle and Neuronal Nicotinic Acetylcholine Receptors
}

\author{
Steven Vernino, Marc Rogers, Kristofer A. Radcliffe, and John A. Dani \\ Division of Neuroscience, Baylor College of Medicine, Houston, Texas 77030-3498
}

\begin{abstract}
A new approach was developed to determine quantitatively the fraction of current carried by $\mathrm{Ca}^{2+}$ through an ion channel under physiological conditions. This approach entails the simultaneous measurement of membrane current and intracellular $\mathrm{Ca}^{2+}$ for single cells. Whole-cell patch-clamp techniques were used to measure current, and intracellular $\mathrm{Ca}^{2+}$ was monitored with the fluorescent indicator fura-2. To obtain a quantitative measure of the fraction of current carried by $\mathrm{Ca}^{2+}$, a cell-by-cell calibration method was devised to account for differences among cells in such factors as cellular volume and $\mathrm{Ca}^{2+}$ buffering. The method was used to evaluate the $\mathrm{Ca}^{2}+$ flux through muscle and neuronal nicotinic ACh receptors (nAChRs). In a solution containing $2.5 \mathrm{~mm}$ $\mathrm{Ca}^{2+}$ at a holding potential of $-50 \mathrm{mV}, \mathrm{Ca}^{2+}$ carries $2.0 \%$ of the inward current through muscle nAChRs from BC3H1 cells and $4.1 \%$ of the inward current through neuronal nAChRs from adrenal chromaffin cells. The $\mathrm{Ca}^{2+}$ flux through neuronal nAChRs of adrenal chromatfin cells is insensitive to $\alpha$-bungarotoxin. The influx of $\mathrm{Ca}^{2+}$ is voltage dependent, and because of the $\mathrm{Ca}^{2+}$ concentration difference across the cellular membrane, there is $\mathrm{Ca}^{2+}$ influx into the cell even when there is a large net outward current. At both muscle and neuronal cholinergic synapses, activity-dependent $\mathrm{Ca}^{2+}$ influx through nicotinic receptors produces intracellular signals that may have important roles in synaptic development, maintenance, and plasticity.
\end{abstract}

[Key words: cholinergic, permeability, selectivity, ion channel, synaptic transmission, fura-2, patch clamp]

Nicotinic ACh receptors (nAChRs) form a family of ligandgated cation-selective channels in vertebrate neurons and muscle cells (review: Sargent, 1993). The many subtypes of nAChRs can be classified into three main functional categories: muscle nAChRs, neuronal nAChRs, and neuronal $\alpha$-bungarotoxin $(\alpha-$ BGT) binding proteins. Muscle nAChRs mediate the high efficiency synaptic transmission at the vertebrate neuromuscular junction. Neuronal nAChRs are a more diverse second category composed of many different subunits. Genetic diversity in the subunit composition of the neuronal receptor subtypes probably underlies the functional and pharmacological diversity that has been observed (Mathie et al., 1987; Moss et al., 1989; Papke et

\footnotetext{
Received Sept. 2, 1993; revised Mar. 11, 1994; accepted Mar. 24, 1994.

We thank Dr. Aaron Fox for much technical advice used in building the experimental setup. This work was supported by the Muscular Dystrophy Association, by the Whitaker Foundation, and by the National Institutes of Health Grant NS 21229.

Correspondences should be addressed to John $A$. Dani at the above address.

Copyright (C) 1994 Society for Neuroscience $0270-6474 / 94 / 145514-11 \$ 05.00 / 0$
}

al., 1989; Luetje et al., 1990; Mulle and Changeux, 1990; Luetje and Patrick, 1991). Neuronal nAChRs are not inhibited by $\alpha$-BGT (Ascher et al., 1979; Boulter et al., 1987; Lipton et al., 1987; Luetje et al., 1990), but there is a third category of $\alpha$-BGT binding proteins homologous to nAChRs (Carbonetto et al., 1978; Conti-Tronconi et al., 1985) that are present in neuronal tissues (Jacob and Berg, 1983; Clarke et al., 1985; Schulz et al., 1991). The function and complete composition of native neuronal $\alpha$-BGT receptors is still unknown, but the homo-oligomeric channels formed by $\alpha 7$ in oocytes are inhibited by $\alpha$-BGT (Couturier et al., 1990; Schoepfer et al., 1990; Séguéla et al., 1993) as are some nicotinic currents in the CNS (Alkondon and Albuquerque, 1991; Zorumski et al., 1992). Therefore, it is possible that high-affinity neuronal $\alpha$-BGT receptors also can function as ion channels under some circumstances (Zhang et al., 1994).

We and our collaborators have differentiated the three categories of nAChRs based on their ability to permeate calcium ions (Decker and Dani, 1990; Vernino et al., 1992; Séguéla et al., 1993). Muscle nAChRs have a small, but significant, $\mathrm{Ca}^{2+}$ permeability (Katz and Miledi, 1969; Adams et al., 1980; Decker and Dani, 1990). Based on reversal potential measurements, neuronal nAChRs are more permeable than muscle nAChRs to $\mathrm{Ca}^{2+}$ (Fieber and Adams, 1991; Sands and Barish, 1991; Vernino et al., 1992). In the oocyte expression system, $\alpha 7$ homooligomer nAChRs sensitive to $\alpha$-BGT are even more permeable to $\mathrm{Ca}^{2+}$ than are traditional neuronal nAChRs (Séguéla et al., 1993).

The $\mathrm{Ca}^{2+}$ permeability of $\mathrm{nAChRs}$ is of interest because synaptic activity can generate intracellular and extracellular $\mathrm{Ca}^{2+}$ signals that influence cellular excitability. For example, nicotinic activity can produce intracellular $\mathrm{Ca}^{2+}$ signals that lead to the activation of $\mathrm{Ca}^{2+}$-dependent ion channels (Tokimasa and North, 1984; Fuchs and Morrow, 1992; Vernino et al., 1992). Activitydependent decreases in extracellular $\mathrm{Ca}^{2+}$ throughout the central nervous system also are large enough to provide important extracellular signals (see Heinemann et al., 1990). For example, neuronal nAChRs are directly modulated by extracellular $\mathrm{Ca}^{2+}$ in a dose-dependent manner (Mulle et al., 1992b; Vernino et al., 1992). Thus, nAChRs can act both as initiators of $\mathrm{Ca}^{2+}$ signals and as targets for $\mathrm{Ca}^{2+}$-dependent modulation.

The purpose of these experiments was to measure quantitatively the $\mathrm{Ca}^{2+}$ flux through nAChRs under physiological conditions. A new approach was developed to determine the fraction of current through nAChRs carried by $\mathrm{Ca}^{2+}$. The current through nAChRs was measured using whole-cell patch-clamp techniques while simultaneously monitoring the concentration of intracellular $\mathrm{Ca}^{2+}$ using the indicator fura-2. The approach required a cell-by-cell calibration that related a fura- 2 signal to 
a specific influx of $\mathrm{Ca}^{2+}$. The calibration controlled for differences among cells in their cellular volume and $\mathrm{Ca}^{2+}$ buffering.

\section{Materials and Methods}

Cell culture. Neuronal nAChR channels were studied in bovine and rat adrenal chromaffin cells. Adrenal chromaffin cells were isolated from the rat adrenal medulla using methods similar to Akaike et al. (1990). Young adult Sprague-Dawley rats (Sasco) were sacrificed in a carbon dioxide euthanasia chamber (CarboBox, Humane Causes Inc.), and adrenal glands were quickly removed and washed with ice-cold, low $\mathrm{Ca}^{2+}$ buffer. Adrenal medullae were isolated from the adrenal cortex and connective tissue, chopped into four to eight pieces, rinsed with cold low $\mathrm{Ca}^{2+}$ buffer, and incubated for $15 \mathrm{~min}$ at $37^{\circ} \mathrm{C}$ in low $\mathrm{Ca}^{2+}$ buffer containing $0.3 \%$ collagenase (Worthington Biochemical Corp.). The tissue was washed several times, dissociated in DMEM plus $1 \%$ bovine serum albumin, and plated onto coated coverslips on the bottoms of modified culture dishes. Some cells were incubated in serum-free media and were used acutely (3-8 hr after plating). Other cells were cultured in media containing $10 \%$ heat-inactivated fetal bovine serum (FBS, GIBCO) and were used for 1-2 d. As we have described previously (Vernino et al., 1992), bovine chromaffin cells were prepared using a protocol similar to that described above. The bovine cells were studied 5-20 d after plating. All of the cells were stored in an incubator at $37^{\circ} \mathrm{C}$ with $5 \% \mathrm{CO}_{2}$.

Each $35 \mathrm{~mm}$ culture dish (Falcon 3001) had a hole drilled in its bottom. A coverslip was mounted with Sylgard silicone elastomer (Dow Corning) over the hole. The coverslip was then coated with collagen and poly-D-lysine. The experiments were done on the cells in these thin glass-bottomed culture dishes so that excitation light at $340 \mathrm{~nm}$ and $380 \mathrm{~nm}$ could pass through to reach the fura-2 inside the cells.

Clonal BC3H1 mouse muscle cells were used to study embryonictype skeletal muscle nAChRs. BC3H1 cells were maintained using standard techniques (see Dani, 1989) in DMEM containing 15\% FBS (GIB$\mathrm{CO}$ or Hyclone) at $37^{\circ} \mathrm{C}$ with $5 \% \mathrm{CO}_{2}$. The cells were passed when they became about $70 \%$ confluent. For patch-clamp experiments, the cells were plated onto uncoated coverslips at the bottoms of the modified culture dishes. The cells were maintained in DMEM with $0.5 \% \mathrm{FBS}$, which induced differentiation and increased the production of $\mathrm{nAChRs}$. The media was changed every other day, and the cells were used 4-12 d after plating.

Whole-cell recording and solution-exchange techniques. Whole-cell nAChR currents were measured in chromaffin and BC $3 \mathrm{H} 1$ cells using standard patch-clamp techniques (Hamill et al., 1981). Patch pipettes were pulled from borosilicate glass (Garner Glass Co.) and coated with Sylgard silicone elastomer. Pipette tips were polished immediately before the experiment using a microforge (Narishige USA). Currents were amplified and filtered (four-pole Bessel filter) using a Dagan 3900A or Warner 501A patch-clamp amplifier.

Fast agonist applications were made with large outflow tubes (375 $\mu \mathrm{m}$ inner diameter glass pipettes) that were positioned in a row (Amador and Dani, 1991; Vernino et al., 1992). The outtlow tubes were mounted on a high-speed motorized manipulator (Newport Corp.) so that they could be repositioned rapidly for solution changes that were complete in tens of milliseconds. The solution bathing the cell was changed by moving the outflow tubes from one containing pure external solution to one containing the external solution with agonist added. The movement of the motorized manipulators was controlled by trigger pulses from the computer. Therefore, the solution changes were rapid and timed for reproducible agonist applications even in total darkness.

Solutions. Based on the results from preliminary experiments, external solutions were chosen to isolate nAChR currents from other membrane conductances. Extracellular test solutions contained (in mM) 150 $\mathrm{NaCl}, 0-5 \mathrm{CaCl}_{2}, 0-1 \mathrm{MgCl}_{2}$, and 10 HEPES; the extracellular pure $\mathrm{Ca}^{2+}$ solution contained $75 \mathrm{CaCl}_{2}$ and 10 HEPES. Solutions were adjusted to $\mathrm{pH} 7.4$ with the hydroxide of the major cation and were osmotically adjusted to 0.3 osmolal with sucrose. All external test solutions additionally contained $0.5 \mu \mathrm{M}$ atropine to inhibit muscarinic responses and 25-250 nM TTX to block voltage-dependent $\mathrm{Na}^{+}$channels. A nicotinic specific agonist, 1,1-dimethyl-4-phenylpiperizinium (DMPP), was usually used to elicit nAChR currents.

Intracellular solutions were also chosen to promote large $n A C h R$ currents while inhibiting other channels. Pipette solutions contained (in mM) 140 cesium methanesulfonate (Cs- $\mathrm{CH}_{3} \mathrm{SO}_{3}$ ) or $140 \mathrm{~N}$-methyl-Dglucamine (NMG), $1 \mathrm{Mg}$-ATP, 5 tetraethylammonium chloride (TEA),
0.2 EGTA, 0.1 or 0.4 or 1 fura-2, and 20 HEPES. The solution was adjusted to $\mathrm{pH} 7.4$ with methanesulfonic acid.

Because NMG does not carry current through nAChRs, the internal solution containing NMG was practically a solution of impermeant ions. With this impermeant internal solution, $\mathrm{nAChR}$ currents were unidirectional, inward currents. The nicotinic agonist DMPP induced inward currents at potentials up to $+75 \mathrm{mV}$, and outward currents were never seen. With the $\mathrm{Cs}^{+}$internal solution, $\mathrm{nAChR}$ currents were bidirectional, and DMPP-induced currents had reversal potentials near $0 \mathrm{mV}$. The $\mathrm{Cs}^{+}$internal solution was used to approximate physiological conditions where there is bidirectional, net current through nAChRs.

The experimental conditions ensured that the currents were only due to ion flux through $n A C h R s$. Voltage-dependent and $\mathrm{Ca}^{2+}$-dependent channels were inhibited by voltage clamping and by the ionic composition of the internal and external solutions. Voltage-dependent $\mathrm{Ca}^{2+}$ channels rapidly ran down under our experimental conditions (similar to Fenwick et al., 1982). Voltage-dependent and $\mathrm{Ca}^{2+}$-activated $\mathrm{K}^{+}$ channels were inhibited by replacing intracellular $\mathrm{K}^{+}$with $\mathrm{Cs}^{+}$and TEA. $\mathrm{Ca}^{2+}$-activated $\mathrm{Cl}^{-}$conductances were eliminated by replacing intracellular $\mathrm{Cl}^{-}$with the impermeant anion methanesulfonate. In some experiments, both internal and external $\mathrm{Cl}^{-}$were replaced by methanesulfonate. This manipulation did not affect the fraction of current carried by $\mathrm{Ca}^{2+}$, indicating that $\mathrm{Ca}^{2+}$-activated $\mathrm{Cl}^{-}$current did not contaminate these results. After establishing the proper conditions for these experiments, we never saw slowly inactivating tail currents suggestive of $\mathrm{Ca}^{2+}$-activated conductances.

Fura-2 microfluorimetry. Simultaneous measurements of the intracellular calcium concentration and membrane current were made at the single cell level using instrumentation adapted from the methods of Thayer et al. (1988b). The cell-impermeant pentapotassium salt of fura-2 (Molecular Probes) was introduced into the cell through the patch pipette at a concentration of $100 \mu \mathrm{M}$ or $400 \mu \mathrm{M}$ with $200 \mu \mathrm{M}$ EGTA or alone at $1 \mathrm{~mm}$. Excitation light was generated by a modified Deltascan-1 (Photon Technologies) containing a $100 \mathrm{~W}$ mercury lamp. A five-blade mirror spinning at $30 \mathrm{~Hz}$ alternated the incident light between two monochrometers set at wavelengths of 340 and $380 \mathrm{~nm}$. Output light from the monochrometers was combined in a random bundle fiber optic, passed through a diffusing lens into the epifluorescence port of a Nikon Diaphot microscope, and focused on the specimen via an oil-immersion ultraviolet $100 \times$ objective.

The intracellular $\mathrm{Ca}^{2+}$ concentration was measured by monitoring the ratio of fura-2 fluorescence emission above $480 \mathrm{~nm}$ with a photomultiplier tube (Thorn-EMI). The output then passed through a discriminator (Thorn-EMI) and into a counter of an analog-to-digital board (TL-1, Axon Inst.). A rectangular diaphragm along the path of the fluorescence light allowed us to define the area of the cell used for the ratio measurement. This area of the cell that was used always excluded the patch pipette, which was filled with fura- 2 and was the main source of background fluorescence. A small background correction, ranging from 0 to $8 \%$, was made before calculating the fluorescence intensity ratio.

Standard methods were used to estimate the absolute values of the $\mathrm{Ca}^{2+}$ concentration (Thayer et al., 1988b) from the fura-2 ratio measurements based on the following equation (Grynkiewicz et al., 1985): $\left[\mathrm{Ca}^{2+}\right]=K\left(R-R_{\min }\right) /\left(R_{\max }-R\right)$, where $R$ is the measured ratio of fura-2 fluorescence at incident wavelengths of $340 \mathrm{~nm}$ and $380 \mathrm{~nm}$. Calibration solutions containing known amounts of free calcium were prepared based upon a computer program by Fabiato (1988). In addition to the method using simple solutions of $\mathrm{Ca}^{2+}$, two methods using individual cells were also used to calibrate the fura- 2 signal for the absolute $\mathrm{Ca}^{2+}$ concentration. In the first method, a cell was perfused by an internal solution containing $100 \mu \mathrm{M}$ fura-2. Then, the cell was exposed to a $\mathrm{Ca}^{2+}$ ionophore (4-Br-A23187, Molecular Probes) in an external solution of either $10 \mathrm{~mm}$ EGTA or $2 \mathrm{~mm} \mathrm{Ca}{ }^{21}$. In the second method, a cell was perfused with an internal solution containing fura-2 and either $10 \mathrm{mM}$ EGTA or $2 \mathrm{mM} \mathrm{CaCl}_{2}$. The fura-2 ratios gave $R_{\min }$ in the $10 \mathrm{~mm}$ EGTA solution and gave $R_{\max }$ in the $2 \mathrm{mM} \mathrm{Ca}^{2+}$ solution. Taken together, the calibrations gave values for $K, R_{\min }$, and $R_{\max }$ of $1.0 \mu \mathrm{M}, 0.1$, and 3 , which were used to compute the intracellular $\mathrm{Ca}^{2+}$ concentration from fura- 2 ratio measurements. These values are within the range used by others (Grynkiewicz et al., 1985; Thayer et al., 1988a; Mulle et al., 1992a).

Fluorescence intensity and patch-clamp currents were recorded simultaneously. These data were sampled alternately and interleaved into computer memory so that the temporal correlation between the two types of data was maintained. For these experiments, the current was 

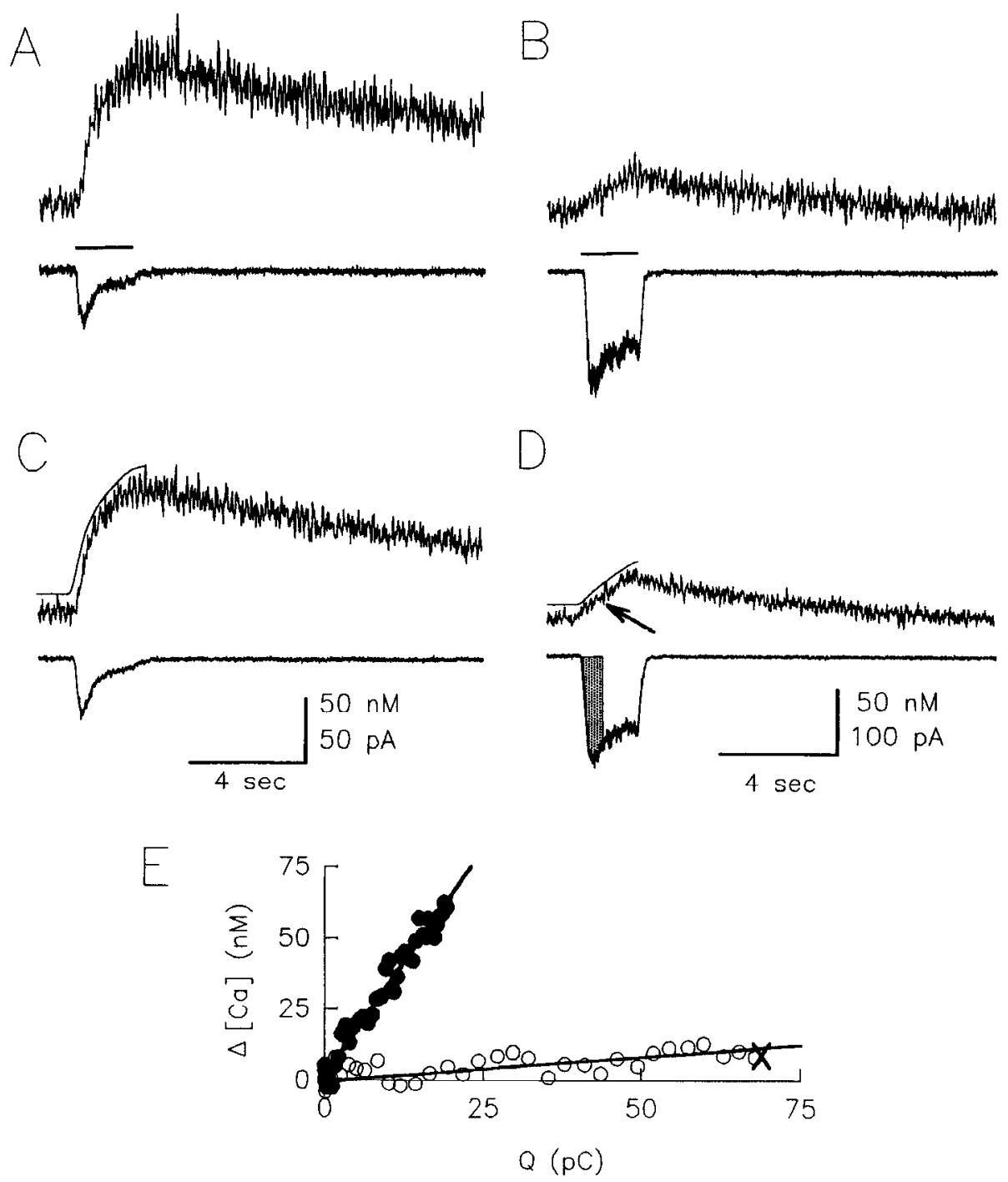

Figure 1. Calcium influx through ganglionic-type neuronal nAChRs. Single simultaneous recordings of current (lower) and intracellular Ca ${ }^{2+}$ concentration (upper) are shown for an adrenal chromaffin cell in a pure external $\mathrm{Ca}^{2+}$ solution $(A)$ and in a physiologic solution containing 2.5 $\mathrm{mM} \mathrm{Ca}{ }^{2+}(B)$. The agonist was $25 \mu \mathrm{M}$ DMPP, and the cell was held at $-50 \mathrm{mV}$. The horizontal bars indicate the computer-controlled application of agonist, which was the same for all the records that are shown. The cell was perfused with the impermeant internal solution. To increase the signal-to-noise ratio, three recordings in pure external $\mathrm{Ca}^{2+}(C)$ and three recordings in physiologic solution $(D)$ were averaged. The integrated currents are shown as smooth curves just above the fura- 2 records. The curves are slightly displaced so it can be seen that the shape of the integrated current follows the fura-2 signal beyond the time used in the analysis (the shaded area out to $0.8 \mathrm{sec}$ ). $E$, The fraction of current carried by $\mathrm{Ca}^{2+}$ was determined by plotting the change in intracellular $\mathrm{Ca}^{2+}(\Delta[\mathrm{Ca}])$ against the cationic influx (charge, $Q$ ). In pure external $\mathrm{Ca}^{2+}(\Theta)$, current is carried exclusively by $\mathrm{Ca}^{2+}$ ions, and the linear regression line associating intracellular $\mathrm{Ca}^{2+}$ to the incoming charge is steep. In physiologic solution $(0)$, most of the current is carried by $\mathrm{Na}^{+}$, and only a fraction of the current is carried by $\mathrm{Ca}^{2+}$. The $\times$ data point serves as an example of how the raw data are plotted. The current is integrated to determine the influx of cationic charge. The charge is represented by the shaded area bounded by the current in $D$. The change in the intracellular $\mathrm{Ca}^{2+}$ concentration that is associated with that charge is labeled by an arrow in $D$. The $\times$ data point represents the associated charge and change in $\mathrm{Ca}^{2+}$. Such a data point can be determined at different times along the record.

sampled every $4 \mathrm{msec}$, and fluorescence intensity was sampled every 2 msec. Fluorescence intensity samples were averaged so that a ratio was calculated every $17 \mathrm{msec}$. Data acquisition and analysis (AXOBASIC, Axon Instruments) was performed using a personal computer equipped with an interface board (TL-1, Axon Inst.).

\section{Results}

Fraction of unidirectional, inward current carried by $\mathrm{Ca}^{2+}$ and validity of the approach

Simultaneous recordings of DMPP-induced current and the concentration of intracellular $\mathrm{Ca}^{2+}$ were used to determine the fraction of current carried by $\mathrm{Ca}^{2+}$. Figure 1 shows data from a whole-cell voltage-clamped chromaffin cell perfused with the impermeant internal solution. Under these electrolyte conditions only unidirectional, inward current passes through the nAChR channels. Simultaneous recordings are shown in pure external $\mathrm{Ca}^{2+}$ (Fig. 1 $A$ ) and in the external solution containing $2.5 \mathrm{mM} \mathrm{Ca}^{2+}$ (Fig. $1 B$ ). Usually, multiple recordings were averaged together to improve the signal-to-noise relationship of the data (Fig. $1 C, D$ ). The number of records that was averaged depended on how long the whole-cell voltage-clamp lasted. Because agonist applications were controlled by computer, successive recordings aligned very well, making signal averaging an easy and effective way to reduce the noise.

The fraction of current carried by $\mathrm{Ca}^{2+}$ was determined by comparing simultaneous current and fura- 2 recordings in a 
physiologic solution of $\mathrm{Ca}^{2+}$ with those in pure external $\mathrm{Ca}^{2+}$. In pure external $\mathrm{Ca}^{2+}$, the inward current is carried exclusively by $\mathrm{Ca}^{2+}$. Therefore, a particular fura- 2 response can be associated with a known $\mathrm{Ca}^{2+}$ influx. This association serves as a phenomenological calibration of the fura-2 response to $\mathrm{Ca}^{2+}$ for each cell. The cell-by-cell calibration allows comparison among cells by avoiding artifacts related to cellular variables such as volume, transport processes, and $\mathrm{Ca}^{2+}$ buffering. With these pure $\mathrm{Ca}^{2+}$ recordings as calibrations, the magnitude of the $\mathrm{Ca}^{2+}$ concentration change in a physiologic solution indicated how much of the current was carried by $\mathrm{Ca}^{2+}$.

In Figure $1 E$, the change in intracellular $\mathrm{Ca}^{2+}(\Delta[\mathrm{Ca}])$ is plotted against the integral of the membrane current. The current integral indicates the amount of charge $(Q)$ that moved across the membrane through neuronal nAChRs activated by DMPP. After application of agonist, the charge influx (shaded area of Fig. 1D) can be associated with a particular change in the intracellular $\mathrm{Ca}^{2+}$ concentration (arrow in Fig. 1D). In a pure solution of external $\mathrm{Ca}^{2+}$, all the incoming current is carried by $\mathrm{Ca}^{21}$. Therefore, a small charge influx $(Q)$ produces a large change in the $\mathrm{Ca}^{2+}$ concentration $(\Delta[\mathrm{Ca}])$. In the external solution containing $2.5 \mathrm{mM} \mathrm{Ca}^{2+}$, the slope of the $\Delta[\mathrm{Ca}$ ] versus $Q$ plot is smaller because only a fraction of the current is carried by $\mathrm{Ca}^{2+}$. By matching the $\Delta[\mathrm{Ca}]$ in physiologic solution to the amount of pure $\mathrm{Ca}^{2+}$ current that produces the same $\Delta[\mathrm{Ca}]$, the fraction of the current in physiologic solution carried by $\mathrm{Ca}^{2+}$ was determined. The fraction was precisely determined by comparing the slopes of the $\Delta[\mathrm{Ca}]$ versus $Q$ plots for the two solutions (solid lines in Fig. $1 E$ ). With the impermeant internal solution and an external solution containing $2.5 \mathrm{mM} \mathrm{Ca}^{2+}$ at a holding potential of $-50 \mathrm{mV}$, the percentage of inward current carried by $\mathrm{Ca}^{2+}$ through neuronal nAChRs in chromaffin cells is $4.1 \pm$ $0.3 \%(n=15)$. Under identical conditions, the percentage of inward current carried by $\mathrm{Ca}^{2+}$ through muscle nAChRs in $\mathrm{BC} 3 \mathrm{H} 1$ cells is $2.0 \pm 0.1 \%(n=10)$. Again, simultaneous recordings of current and intracellular $\mathrm{Ca}^{2+}$ were made in pure external $\mathrm{Ca}^{2+}$ (Fig. $2 A$ ) and in an external solution containing $2.5 \mathrm{~mm} \mathrm{Ca}^{2+}$ (Fig. $2 B$ ). The percentage of $\mathrm{Ca}^{2+}$ is significantly less for muscle nAChRs than for neuronal nAChRs $(p<0.001)$.

Figures $1 E$ and $2 C$ show that there is a linear relationship between the change in intracellular $\mathrm{Ca}^{2+}$ and the integral of the membrane current. This linear correlation indicates that the measured $\mathrm{Ca}^{2+}$ transient is a direct result of agonist-induced $\mathrm{Ca}^{2+}$ influx and is not affected by $\mathrm{Ca}^{2+}$-induced $\mathrm{Ca}^{2+}$ release from intracellular stores, transport processes, nonlinear $\mathrm{Ca}^{2+}$ buffering, or $\mathrm{Ca}^{2+}$-activated conductances (Thayer and Miller, 1990; Schneggenburger et al., 1993). For example, second messenger-mediated $\mathrm{Ca}^{2+}$ signals or $\mathrm{Ca}^{2+}$-induced $\mathrm{Ca}^{2+}$ release from intracellular stores would have caused the $\Delta[\mathrm{Ca}]-Q$ relationship to be curved upward. A linear $\Delta[\mathrm{Ca}]-Q$ relationship that passed through the origin was always observed as long as the intracellular changes in $\mathrm{Ca}^{2+}$ were not cxtrcmcly largc. A scrics of preliminary experiments enabled us to settle on conservative protocols for maintaining the linear relationship between $\Delta[\mathrm{Ca}]$ and $Q$. We required that the starting concentration of $\mathrm{Ca}^{2+}$ was low (below $100 \mathrm{nM}$ ) and that the intracellular $\mathrm{Ca}^{2+}$ concentration remained less than $400 \mathrm{~nm}$ for the analysis. In addition, although agonist was applied for $2 \mathrm{sec}$, only the first $0.8 \mathrm{sec}$ (shaded area in Fig. $1 D$ ) or less was examined to determine the slope. The remainder of the signal was used to be certain that a linear relationship between $\Delta[\mathrm{Ca}]$ and $Q$ continued well beyond the $0.8 \mathrm{sec}$ that was analyzed.

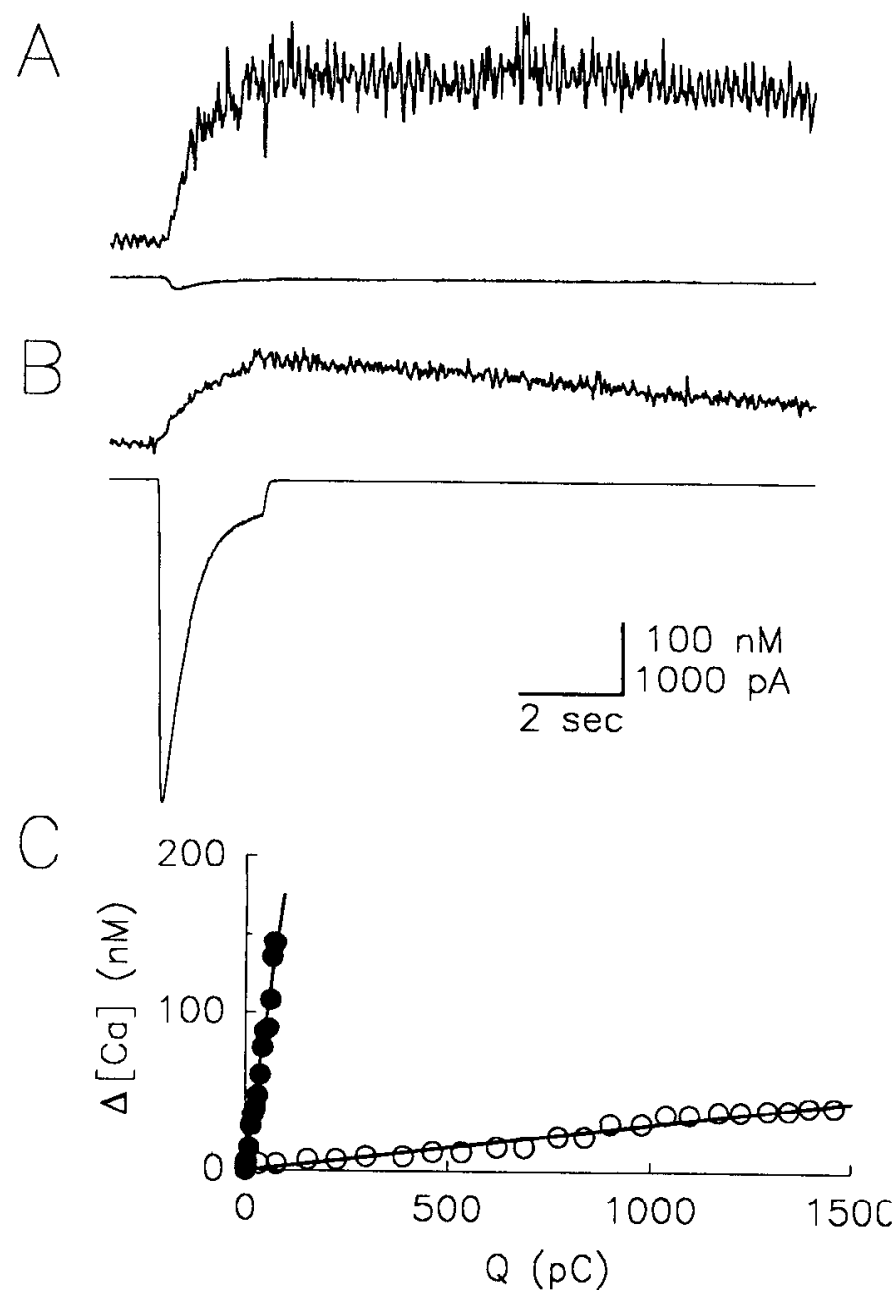

Figure 2. Calcium influx through muscle nAChRs. Simultaneous recordings of $\mathrm{nAChR}$ current and intracellular $\mathrm{Ca}^{2+}$ concentration werc made from a $\mathrm{BC} 3 \mathrm{H} 1$ cell in an external solution of pure $\mathrm{Ca}^{2+}(A)$ and in a $2.5 \mathrm{~mm} \mathrm{Ca}^{2+}$ solution $(B)$. The cell was perfused with an impermeant internal solution and voltage clamped at $-50 \mathrm{mV}$. Currents were induced by $5 \mu \mathrm{M}$ DMPP. Before and between recordings, the cell was incubated in a $\mathrm{Ca}^{2+}$-free solution containing $10 \mathrm{~mm}$ caffeine to deplete intracellular stores of $\mathrm{Ca}^{2+} . C$, The change in intracellular $\mathrm{Ca}^{2+}$ concentration is plotted against the cationic influx in pure $\mathrm{Ca}^{2+}(\bullet)$ and in a physiologic solution of $2.5 \mathrm{~mm} \mathrm{Ca}{ }^{2+}(O)$. The percentage of inward muscle nAChR current carried by $\mathrm{Ca}^{2+}$ for this cell was $2.0 \%$.

We tested for $\mathrm{Ca}^{2+}$-induced $\mathrm{Ca}^{2+}$ release and uptake mechanisms by determining the fraction of current carried by $\mathrm{Ca}^{2+}$ after depleting $\mathrm{Ca}^{2+}$-sensitive intracellular stores with caffeine. Before and in between recordings, cells were incubated in $\mathrm{aCa}^{2+}$ free external solution containing $10 \mathrm{~mm}$ caffeine. Caffeine causes the release of $\mathrm{Ca}^{2+}$ from $\mathrm{Ca}^{2+}$-sensitive intracellular stores (Lipscombe et al., 1988; Malgaroli et al., 1990), and the $\mathrm{Ca}^{2+}$-free solution prevents these stores from refilling (Thayer et al., 1988a). Only the first acute application of $10 \mathrm{~mm}$ caffeine produced a $\mathrm{Ca}^{2+}$ transient in chromaffin cells bathed in $10 \mathrm{~mm}$ EGTA, but this response was not repeatable during whole-cell perfusion, suggesting that caffeine treatment effectively depleted calcium stores. The measured fraction of current carried by $\mathrm{Ca}^{2+}$ was unaffected by this procedure (see Fig. 3D). In addition, hall of the 10 measurements with $\mathrm{BC} 3 \mathrm{H} 1$ cells were conducted with 1-3 $\mu \mathrm{M}$ thapsigargin in the internal solution to inhibit $\mathrm{Ca}^{2+}$ uptake into stores. The fraction of current carried by $\mathrm{Ca}^{2+}$ was 
Figure 3. The approach is not sensitive to the rate of $\mathrm{Ca}^{2+}$ influx. Simultaneous recordings are shown of agonist-induced current and the intracellular $\mathrm{Ca}^{2+}$ concentration in a chromaffin cell perfused with an impermeant internal solution. Recordings were made in a pure external $\mathrm{Ca}^{2+}$ solution so that the membrane current was carried solely by incoming $\mathrm{Ca}^{2+}$ at a holding potential of $-50 \mathrm{mV}(A)$ and $-10 \mathrm{mV}(B) . C$, The change in intracellular $\mathrm{Ca}^{2+}$ is plotted against the cationic influx for this cell. The $\Delta[\mathrm{Ca}]-Q$ relationships are the same at $-50 \mathrm{mV}$ $(0)$ and at $-10 \mathrm{mV}(\nabla)$ even though the rate of $\mathrm{Ca}^{2+}$ influx is different. $D$, The measured values for the percentage of current carried by $\mathrm{Ca}^{2+}$ through neuronal nAChRs are plotted against the size of the peak current obtained in the $2.5 \mathrm{mM} \mathrm{Ca}^{2+}$ solution. Each data point represents a determination from a single chromaffin cell with (O) or without $(O)$ caffeine treatment, and the averages and SDs are represented by $\square$ and $\square$, respectively.
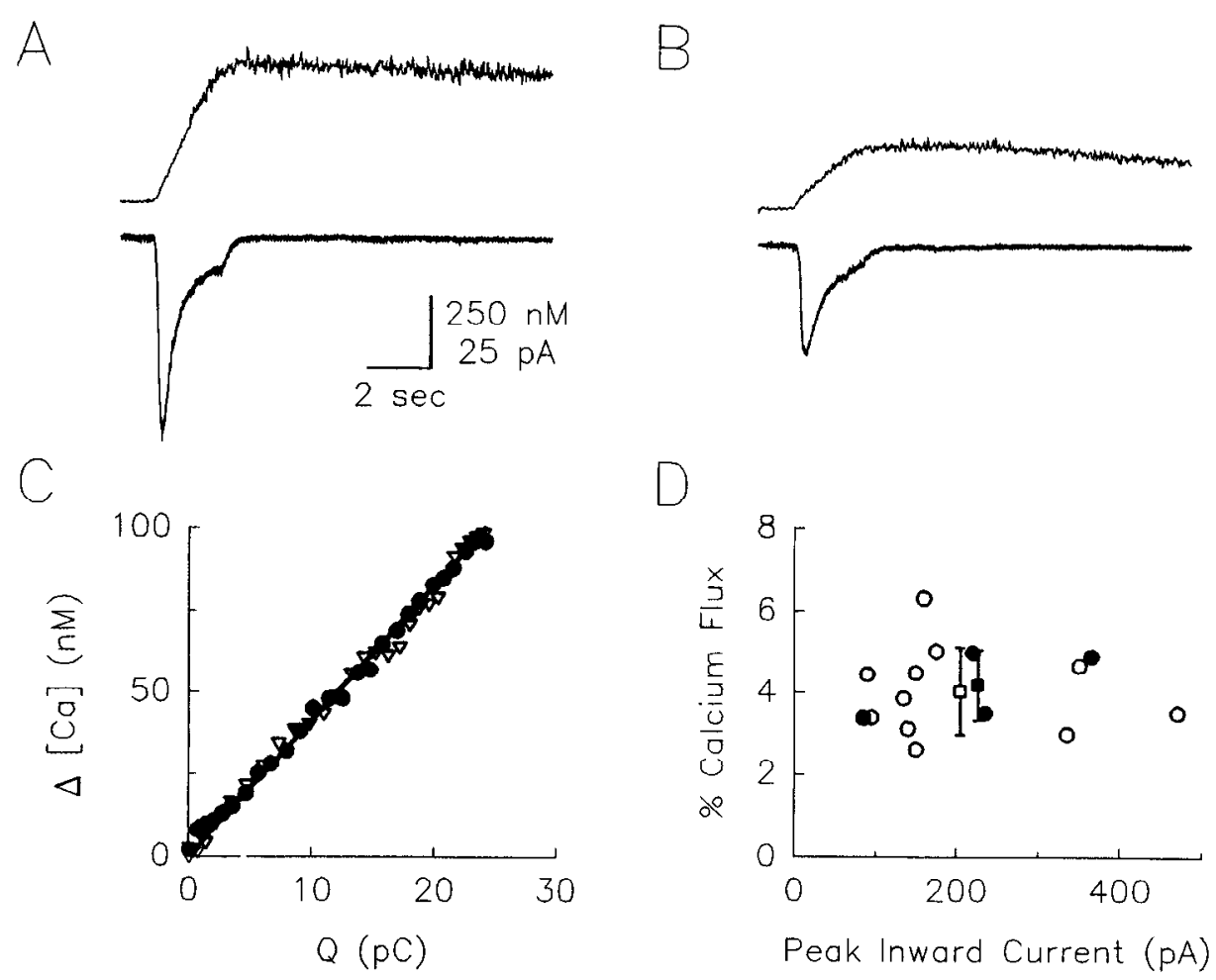

not significantly different with thapsigargin, $1.8 \pm 0.1 \%$, or without, $2.2 \pm 0.2 \%$. The results indicate that $\mathrm{Ca}^{2+}$-induced $\mathrm{Ca}^{2+}$ release or refilling of stores did not influence the results under our experimental conditions.

We also tested for artifacts related to cellular processes by increasing the buffering by fura-2. Usually the experiments were performed with $0.1 \mathrm{~mm}$ fura- 2 and $0.2 \mathrm{~mm}$ EGTA perfusing the cell. Under those conditions, the percentage of inward current carried by $\mathrm{Ca}^{2+}$ through $\mathrm{BC} 3 \mathrm{H} 1$ muscle nAChRs was $2.0 \pm$ $0.2 \%(n=7)$ in $2.5 \mathrm{mM} \mathrm{Ca}^{2+}$. When the buffering of the perfusate was increased to $0.4 \mathrm{~mm}$ fura- 2 and $0.2 \mathrm{~mm}$ EGTA, exactly the same percentage of $\mathrm{Ca}^{2+}$ was measured: $2.0 \pm 0.2 \%(n=3)$. We further assessed the effects of fura- 2 buffering in neuronal cells by increasing the fura- 2 concentration to $1 \mathrm{mM}$, with no added EGTA. These experiments were carried out on rat sympathetic neurons, which are analogous to chromaffin cells in expressing ganglionic-type nAChRs. In three sympathetic neurons, the fraction of inward current carried by $\mathrm{Ca}^{2+}$ through neuronal $\mathrm{nAChRs}$ was $4.7 \pm 0.2 \%$. This value is not statistically different from the average of $4.4 \pm 0.4 \%(n=4 ; p>0.5)$ obtained with $0.1 \mathrm{~mm}$ fura- 2 in rat chromaffin cells under similar conditions of caffeine pretreatment (see Fig. $3 D$ ). These results indicate that cellular buffering or other cellular processes are not affecting the measurements. If they were, the percentage $\mathrm{Ca}^{2+}$ determination would depend on the concentration of exogenous $\mathrm{Ca}^{2+}$ buffers.

Several other potential problems also had to be considered. Experiments were conducted to show that the phenomenological relationship between the intracellular $\mathrm{Ca}^{2+}$ signal and the charge influx was not sensitive to the absolute rate of $\mathrm{Ca}^{2+}$ influx. This possible problem was minimized by having the $\mathrm{Ca}^{2+}$ influxes be of similar size in both pure $\mathrm{Ca}^{2+}$ and the test solution. Figure 3 shows, however, that pure $\mathrm{Ca}^{2+}$ currents of different sizes produce the same calibration slope in a chromaffin cell perfused with the impermeant internal solution. The pure $\mathrm{Ca}^{2+}$ current at $-50 \mathrm{mV}$ (Fig. $3 A$ ) is larger than the $\mathrm{Ca}^{2+}$ current at $-10 \mathrm{mV}$ (Fig. $3 B$ ). Despite the difference in the rate of $\mathrm{Ca}^{2+}$ influx, the change in intracellular $\mathrm{Ca}^{2+}$ per unit charge is the same (Fig. $3 C$ ): the $\Delta[\mathrm{Ca}]-Q$ relationships overlap. This control experiment was pursued further in $\mathrm{BC} 3 \mathrm{H} 1$ cells. By altering the holding potential and the agonist application, the size of the pure $\mathrm{Ca}^{2+}$ currents obtained with a single cell was varicd from three- to ninefold. In all six cells that were tested, the slopes of the $\Delta[\mathrm{Ca}]-$ $Q$ relationships were not dependent on the rate of the $\mathrm{Ca}^{2+}$ influx. The average slope was $0.64 \pm 0.15 \mathrm{nM} / \mathrm{pC}$ for the larger current and $0.65 \pm 0.16$ for the smaller current. Figure $3 D$ further shows that the percentage $\mathrm{Ca}^{2+}$ determination was independent of the charge influx. There is no correlation between the amount of charge entering the cell and the measured percentage of that charge contributed by $\mathrm{Ca}^{2+}$. The validity of the approach is supported by the finding that many different cells with different morphologies and different $\mathrm{nACh}$ densities gave the same result for the fraction of current carried by $\mathrm{Ca}^{2+}$. Furthermore, several concentrations of different agonists gave the same results. Problems related to differences in the spatial distribution of the incoming $\mathrm{Ca}^{2+}$ were avoided because the pure $\mathrm{Ca}^{2+}$ signal used for the calibration and the test solution signal both arise from $\mathrm{Ca}^{2+}$ influx through the same $\mathrm{nAChRs}$. The distribution of the $\mathrm{Ca}^{2+}$ influx is the same for both solutions. All of these results support the accuracy of the approach, which overcomes the inherent shortcomings of fura- 2 as a quantitative $\mathrm{Ca}^{2+}$ indicator

The approach also has some intrinsic strengths. Because each cell is calibrated and the fura- 2 response for the test solution is compared to the calibration, the approach is quite insensitive to changes in the fura- 2 calibration constants, $K, R_{\min }$, and $R_{\max }$. Arbitrary changes in these values drastically changed the calculated free intracellular $\mathrm{Ca}^{2+}$ concentration but did not affect 
the measured fraction of current carried by $\mathrm{Ca}^{2+}$. Only changes in $\mathrm{Ca}^{2+}$ need be measured not the absolute $\mathrm{Ca}^{2+}$ concentration. Finally, the method avoids quantitative corrections that require a complete understanding of the processes underlying $\mathrm{Ca}^{2+}$ homeostasis, which may vary from cell to cell.

\section{Voltage dependence of $\mathrm{Ca}^{2+}$ influx}

The fraction of current carried by $\mathrm{Ca}^{2+}$ through nAChRs is voltage dependent. Unidirectional, inward currents and the associated $\mathrm{Ca}^{2+}$ transients were recorded at two holding potentials using chromaffin cells in an external solution of $2.5 \mathrm{mM} \mathrm{Ca}^{2+}$ and perfused with the impermeant internal solution. At a holding potential of $-10 \mathrm{mV}$ (Fig. $4 A$ ) the current and the $\mathrm{Ca}^{2+}$ transient are smaller than the current and the $\mathrm{Ca}^{2+}$ transient at $-50 \mathrm{mV}$ (Fig. $4 B$ ). In Figure $4 C$, the change in intracellular $\mathrm{Ca}^{2+}$ concentration $(\triangle[\mathrm{Ca}])$ is plotted against the influx of charge $(Q)$. The slope of the $\Delta[\mathrm{Ca}]$ versus $Q$ plot decreases at $-10 \mathrm{mV}$, indicating that a smaller fraction of the inward current through the neuronal nAChRs is carried by $\mathrm{Ca}^{2+}$ as the cell is depolarized. The percentage of inward current carried by $\mathrm{Ca}^{2+}$ through neuronal nAChRs at $-10 \mathrm{mV}$ is $2.7 \pm 0.5 \%(n=4)$. This value is significantly less than the value of $4.1 \%$ obtained at $-50 \mathrm{mV}$ $(p<0.05)$. The result indicates that the $\mathrm{Ca}^{2+}$ influx is reduced by depolarization more than the $\mathrm{Na}^{+}$influx. Because the cell contains only impermeant ions, the reversal potential for both ions is extremely positive and does not influence the result (see Materials and Methods). The result indicates that the molecular steps for the inward permeation of $\mathrm{Ca}^{2+}$ have a greater voltage dependence than those for the permeation of $\mathrm{Na}^{+}$.

In separate experiments with cells perfused with the $\mathrm{Cs}^{+}$internal solution, the fraction of net current carried by $\mathrm{Ca}^{2+}$ was determined. When agonist is applied, a net current is measured that is composed of inward and outward ion fluxes through the open $\mathrm{nAChR}$ channels, similar to the physiologic situation. Under our experimental conditions, the inward component of the net current is carried by $\mathrm{Na}^{+}$and $\mathrm{Ca}^{2+}$ and the outward component is carried by $\mathrm{Cs}^{+}$.

In chromaffin cells perfused with $\mathrm{Cs}^{+}$, simultaneous recordings of net current and intracellular $\mathrm{Ca}^{2+}$ were made at -50 (Fig. $5 A$ ), -30 (Fig. $5 B$ ), and $-15 \mathrm{mV}$ (Fig. $5 C$ ) with $2.5 \mathrm{~mm}$ $\mathrm{Ca}^{2+}$ in the external solution. In Figure $5 D$, the $\Delta[\mathrm{Ca}]-Q$ relations for these recordings are shown. Under these conditions, the percentage of net neuronal $\mathrm{nAChR}$ current carried by $\mathrm{Ca}^{2+}$ is $4.7 \pm 0.3 \%(n=4)$ at $-50 \mathrm{mV}, 4.4 \pm 0.8 \%(n=3)$ at -30 $\mathrm{mV}$, and $15.6 \%(n=2)$ at $-15 \mathrm{mV}$. The fraction of current carried by $\mathrm{Ca}^{2+}$ appears to increase with depolarization because the net current becomes smaller near the reversal potential. At the reversal potential for monovalent cations (near $0 \mathrm{mV}$ ), the inward and outward components of the current are equal and the net current is zero. Because of the $\mathrm{Ca}^{2+}$ concentration gradient across the membrane, however, $\mathrm{Ca}^{2+}$ current reverses at a much more positive potential and $\mathrm{Ca}^{2+}$ still carries significant inward current well after the net current has reversed. Since the measured net current is smaller than the underlying inward component of the current, $\mathrm{Ca}^{2+}$ appears to carry a greater fraction of the net current. For example, at $-50 \mathrm{mV}$ the fraction of net current carried by $\mathrm{Ca}^{2+}(4.7 \%)$ is greater than the fraction of one-way inward current carried by $\mathrm{Ca}^{2+}(4.1 \%, p<0.05)$. As the voltage is decreased from -50 to $-30 \mathrm{mV}$, statistically identical percentages are seen because both the net current and the $\mathrm{Ca}^{2+}$ component of the current decrease by comparable
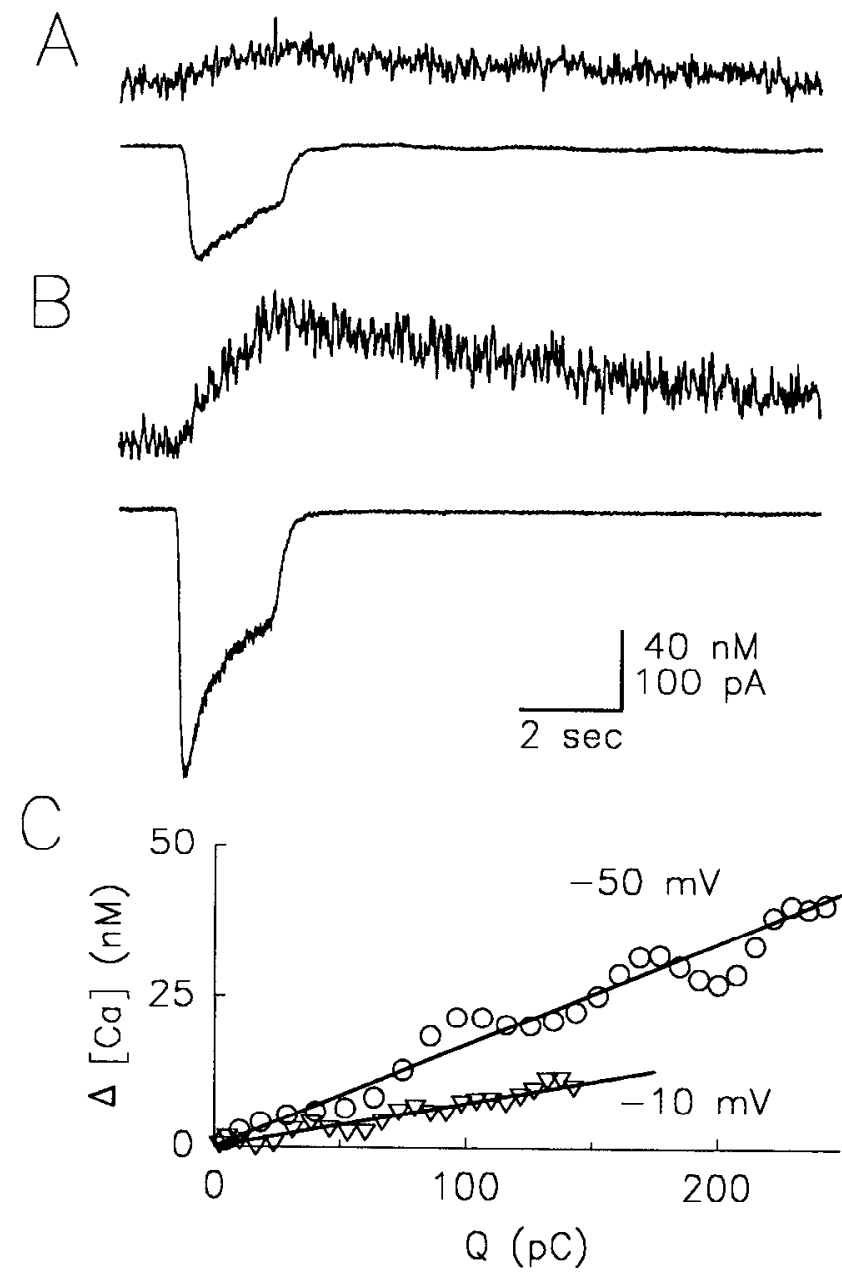

Figure 4. Voltage dependence of the percentage of inward current carried by $\mathrm{Ca}^{2+}$. Simultaneous recordings of DMPP-induced current and intracellular $\mathrm{Ca}^{2+}$ were made in an adrenal chromaffin cell held at $-10 \mathrm{mV}(A)$ and at $-50 \mathrm{mV}(B)$. The external solution contained 2.5 $\mathrm{mM} \mathrm{Ca}{ }^{2+}$, and the cell was perfused with an impermeant internal solution. The currents were induced by $25 \mu \mathrm{M}$ DMPP. Because $\mathrm{Ca}^{2}:$ influx is voltage dependent, the change in intracellular $\mathrm{Ca}^{2+}$ is less pronounced at the depolarized potential. $C$, The change in intracellular $\mathrm{Ca}^{2+}$ is plotted against the cationic influx for recordings made at $-50 \mathrm{mV}(O)$ and at $-10 \mathrm{mV}(\nabla)$. Calcium carries $2.7 \%$ of the inward neuronal $\mathrm{nAChR}$ current at $-10 \mathrm{mV}$ and $4.1 \%$ of the inward neuronal $\mathrm{nAChR}$ current at $-50 \mathrm{mV}$. To simplify the figure, the recordings and calibration line in pure external $\mathrm{Ca}^{2+}$ are not shown.

amounts. At $-15 \mathrm{mV}$, the net current decreases appreciably as the reversal potential for monovalent ions is approached, but the $\mathrm{Ca}^{2+}$ component of the current is not equivalently reduced; thus, a high percentage (15.6\%) is measured.

The apparent fraction of net current carried by $\mathrm{Ca}^{2+}$ was also determined for the muscle $\mathrm{nAChRs}$ of $\mathrm{BC} 3 \mathrm{H} 1$ cells under physiologic conditions. At $-50 \mathrm{mV}, \mathrm{Ca}^{2+}$ carries $2.3 \%$ of the net current ( $2.4 \%$ and $2.2 \%, n=2)$. Again, since $\mathrm{Ca}^{2+}$ is essentially absent inside the cell, $\mathrm{Ca}^{2+}$ carries only inward current at all potentials. Figure 6 demonstrates that nAChRs can allow $\mathrm{Ca}^{2+}$ influx even at positive potentials where the measured net membrane current is outward. For this experiment, agonist was applied to a $\mathrm{BC} 3 \mathrm{H} 1$ cell perfused with $\mathrm{Cs}^{+}$and held at $+20 \mathrm{mV}$. The size of the outward current does not correlate with the magnitude of the $\mathrm{Ca}^{2+}$ influx because the $\mathrm{Ca}^{2+}$ current was inward while the net current was outward. 
A

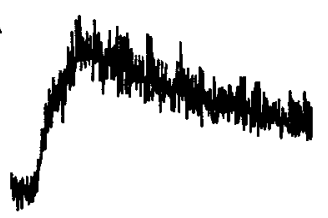

Figure 5. Voltage dependence of the percentage of net current carried by $\mathrm{Ca}^{2+}$. Simultaneous recordings of DMPP-induced current and intracellular $\mathrm{Ca}^{2+}$ were made in an adrenal chromaffin cell perfused with $\mathrm{Cs}^{+}$at $-50 \mathrm{mV}(A)$, at $-30 \mathrm{mV}(B)$, and at $-15 \mathrm{mV}(C) . A$ and $B$ are at the same scale. $D$, The change in intracellular $\mathrm{Ca}^{2+}$ is plotted against the cationic influx for recordings at $-50 \mathrm{mV}(\mathrm{O}),-30$ $\mathrm{mV}(\Delta)$, and $-15 \mathrm{mV}(\diamond)$. A single linear regression line is drawn through the overlapping data at -50 and -30 $\mathrm{mV}$, but the relationship is steeper at $-15 \mathrm{mV}$. The calibration line in pure external $\mathrm{Ca}^{2+}$ is not shown to simplify the graph.

\section{Concentration dependence of the $\mathrm{Ca}^{2+}$ influx}

The agonist-induced $\mathrm{Ca}^{2+}$ influx through nAChRs depends on the concentration of external $\mathrm{Ca}^{2+}$. In a $\mathrm{Ca}^{2+}$-free external solution, large DMPP-induced currents do not produce fura-2 signals in muscle or chromaffin cells (Fig. $7 A, B$ ). When extracellular $\mathrm{Ca}^{2+}$ is present, DMPP-induced currents in the same cells are accompanied by large $\mathrm{Ca}^{2+}$ transients. This result is further evidence that nicotinic receptor activation does not liberate $\mathrm{Ca}^{2+}$ from internal stores, and that there is a direct relationship between calcium influx and the fura- 2 transient. As the external concentration of $\mathrm{Ca}^{2+}$ is increased from 0 to $5 \mathrm{~mm}$, the percentage of inward current carried by $\mathrm{Ca}^{2+}$ through neuronal and muscle nAChRs (Fig. $7 C$ ) increases to $6.3 \pm 0.2 \%(n=4)$ and $3.4 \pm 0.3 \%(n=3)$, respectively.

Agonist-induced currents and $\mathrm{Ca}^{2+}$ signals in chromaffin cells are mediated by traditional neuronal $n A C h R s$

Two sets of experiments were conducted to test whether an unexpected subtype of $\mathrm{nAChR}$ could be contributing to the measured $\mathrm{Ca}^{2+}$ influx. Recent reports have indicated that neuronal receptors sensitive to $\alpha$-bungarotoxin ( $\alpha$-BGT) have a high $\mathrm{Ca}^{2+}$ permeability (Vijayaraghavan et al., 1992; Séguéla et al., 1993). The $\alpha$-BGT-sensitive $\mathrm{Ca}^{2+}$ signal described in ciliary ganglion neurons was maximally activated by $1 \mu \mathrm{M}$ nicotine. It has been suggested that the $\alpha$-BGT binding proteins are preferentially activated by low concentrations of nicotine (Vijayaraghavan et al., 1992), and it has been reported that cloned neuronal $\alpha$-BGT-sensitive nAChRs do not respond to the nicotinic agonist DMPP (Hussy and Bertrand, 1991; but see Séguéla et al., 1993).

One set of experiments tested for an $\alpha$-BGT-sensitive component of the DMPP-induced $\mathrm{Ca}^{2+}$ influx in adrenal chromaffin cells. As found with most other neuronal nicotinic cholinergic responses (Mulle and Changeux, 1990; Vijayaraghavan et al., 1992; Vernino et al., 1992), DMPP-induced currents and $\mathrm{Ca}^{2+}$ signals in chromaffin cells were not affected by a 40 min incu-

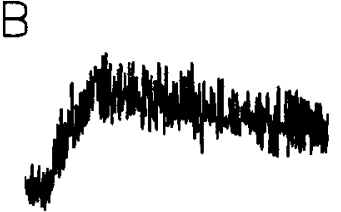

C
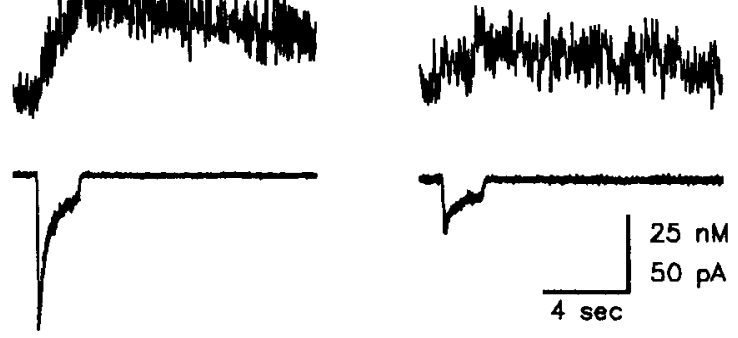

D

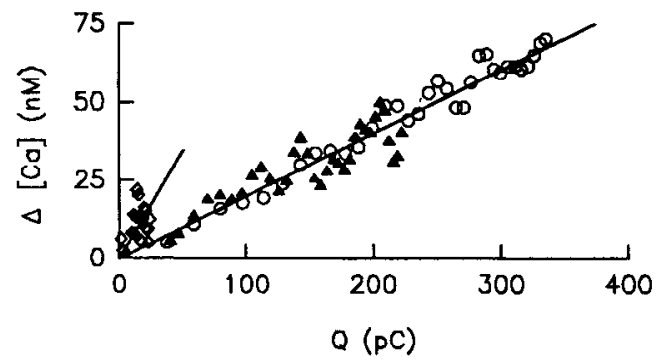

bation in $50 \mathrm{nM} \alpha$-BGT. After $\alpha$-BGT treatment, the fraction of inward ncuronal nAChR current carricd by $\mathrm{Ca}^{2+}$ at $-50 \mathrm{mV}$ was $3.8 \pm 0.6 \%(n=3)$. This value is not significantly different from the fraction of current carried by $\mathrm{Ca}^{2+}$ in untreated chromaffin cells $(4.1 \%, p>0.5)$, suggesting that the $\mathrm{Ca}^{2+}$ influx and current induced by $25 \mu \mathrm{M}$ DMPP in chromaffin cells was due to activation of traditional ( $\alpha$-BGT insensitive) neuronal nAChRs.

To verify that this $\alpha$-BGT treatment was effective, muscle $\mathrm{nAChR}$ currents were recorded in $\mathrm{BC} 3 \mathrm{H} 1$ cells incubated for $40 \mathrm{~min}$ in $50 \mathrm{nM} \alpha$-BGT. Muscle $\mathrm{nAChR}$ currents were reduced from about $1600 \mathrm{pA}$ to $10 \mathrm{pA}$ by the same $\alpha$-BGT incubation that had no affect on neuronal nAChR responses in chromaffin cells.

In a second set of experiments, we evaluated whether there was a population of receptors present in the chromaffin cells that was sensitive to low concentrations of nicotine (Fig. 8). In each of three cells, a $5 \mathrm{sec}$ application of $1 \mu \mathrm{M}$ nicotine failed to induce a measurable membrane current or measurable transient of intracellular $\mathrm{Ca}^{2+}$ (Fig. 8A), but all the cells showed robust responses to $25 \mu \mathrm{M}$ DMPP. To prevent desensitization, the cells were not exposed to any agonist until the first application of nicotine. In another cell, the nicotine concentration was increased to $5 \mu \mathrm{M}$ to elicit responses (Fig. $8 B$ ), and in that same cell the response to $25 \mu \mathrm{M}$ DMPP was measured (Fig. $8 C$ ). Figure $8 D$ shows that $5 \mu \mathrm{M}$ nicotine and $25 \mu \mathrm{M}$ DMPP produce the same change in intracellular $\mathrm{Ca}^{2+}$ per unit influx of charge: the two $\Delta[\mathrm{Ca}]-Q$ relations overlap. The result shows that the $\mathrm{Ca}^{2+}$ permeability of the nAChRs activated by $5 \mu \mathrm{M}$ nicotine is the same as that activated by $25 \mu \mathrm{M}$ DMPP. We found no evidence for a pharmacologically distinct receptor subtype in chromaffin cells with a remarkably different $\mathrm{Ca}^{2+}$ permeability.

\section{Discussion}

We have developed and tested an approach to determine quantitatively the percentage of current carried by $\mathrm{Ca}^{2+}$ through an ion channel. The approach has an inherent strength: for each 

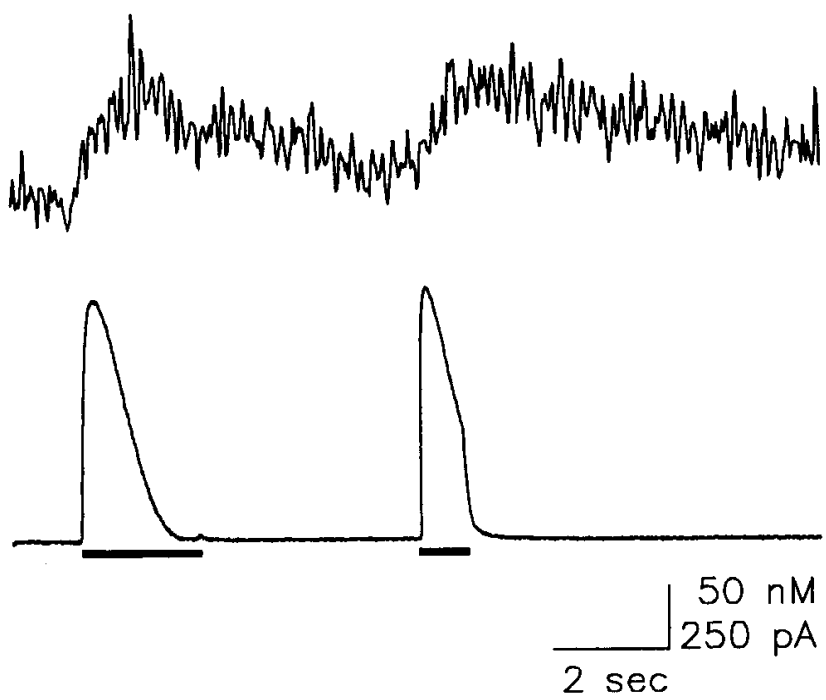

Figure 6. Inward $\mathrm{Ca}^{2+}$ flux during net outward current. A simultaneous recording of DMPP-induced current and intracellular $\mathrm{Ca}^{2+}$ is shown for a $\mathrm{BC} 3 \mathrm{H} 1$ cell perfused by the $\mathrm{Cs}^{+}$-containing internal solution. As indicated by the horizontal bars below the current record, two applications of $25 \mu \mathrm{M}$ DMPP opened muscle nAChRs allowing a $\mathrm{Ca}^{2+}$ influx even though the net current was outward. The cell was held at $+20 \mathrm{mV}$.

cell, the channels used to detcrminc the percentage are the same channels used to calibrate the $\mathrm{Ca}^{2+}$ influx. Therefore, the method avoids artifacts arising from differences among cells or from differences in the local saturation of the fura- 2 because those effects are the same during the percentage measurement and the calibration. Control experiments also showed that our protocols were insensitive to the rate of $\mathrm{Ca}^{2+}$ entry. A nearly 10 -fold change in the rate of $\mathrm{Ca}^{2}$ ' entry and a 10 -fold increase in the fura- 2 concentration did not alter the percentage measurement.

Calcium percentage measurements from other laboratories employed voltage-dependent $\mathrm{Ca}^{2+}$ channels (VDCCs) from different cells to calibrate the $\mathrm{Ca}^{2+}$ influx through ligand-gated channels (Schneggenburger et al., 1993; Trouslard et al., 1993; Zhou and Neher, 1993). With that method, differences between the cells in buffering and intracellular $\mathrm{Ca}^{2+}$ processes need not cancel. Furthermore, VDCCs and ligand-gated channels are not identically distributed so the local saturation of the indicator by the $\mathrm{Ca}^{2+}$ influx will be different during the calibration, which uses VDCCs, and during the percentage measurement, which uses ligand-gated channels.

In this report, we quantitatively determined the $\mathrm{Ca}^{2+}$ flux through muscle nAChRs from $\mathrm{BC} 3 \mathrm{H} 1$ cells and neuronal nAChRs from adrenal chromaffin cells and rat sympathetic neurons. $\mathrm{BC} 3 \mathrm{H} 1$ cells express the embryonic form of the muscle nAChRs that is composed of $\alpha 1_{2} \beta 1 \gamma \delta$. The chromaffin cells and sympathetic neurons express ganglionic-type neuronal $\mathrm{nACh}$ Rs (Mathie et al., 1987; Akaike et al., 1990), which are usually thought to contain $\alpha 3$ (Criado et al., 1992). The genetic diversity of the neuronal $\mathrm{nAChRs}$ raises the possibility that more than one subtype of channel contributes to our measurement. Among the neuronal nAChR subtypes, a significantly different $\mathrm{Ca}^{2+}$ permeability is found only for the $\alpha 7$ homo-oligomer channel expressed in oocytes (Vernino et al., 1992; Séguéla et al., 1993). That homo-oligomer channel is blocked by $\alpha$-BGT, but the measurements with chromaffin cells and sympathetic neurons were not affected by $\alpha$-BGT, eliminating the possibility that an
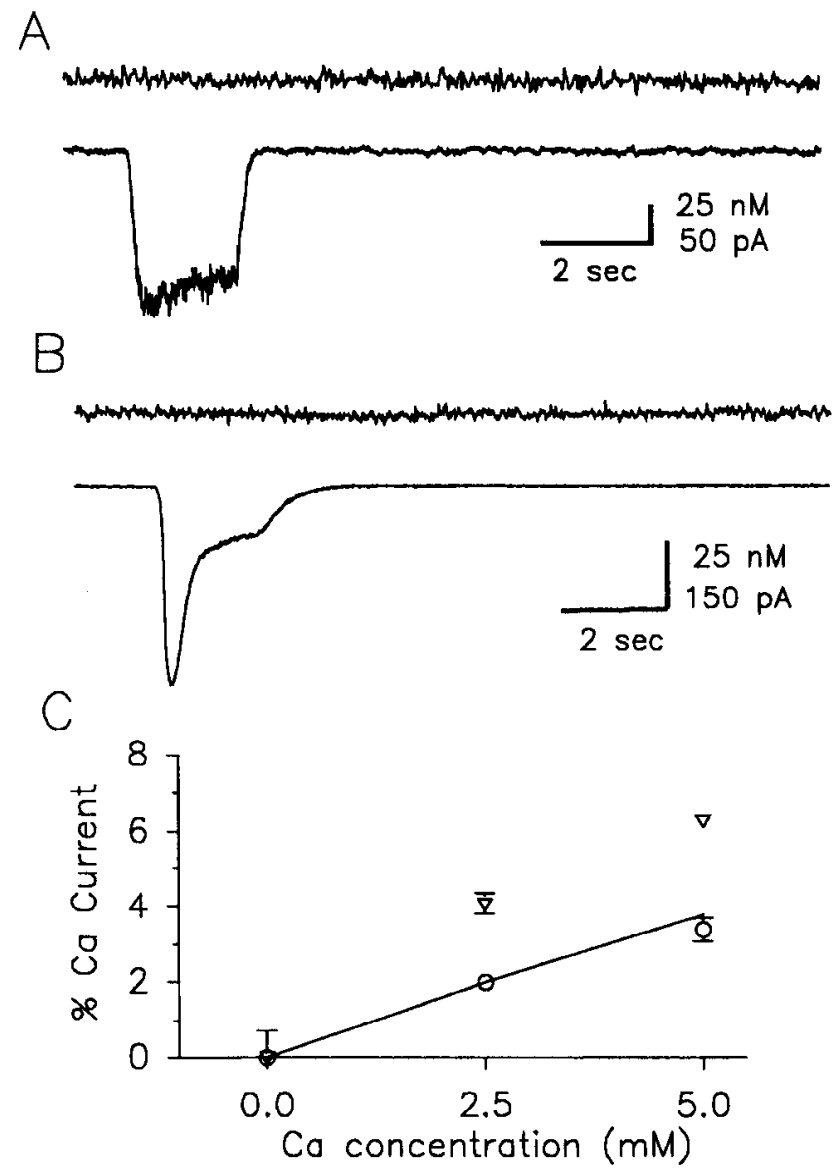

Figure 7. Calcium concentration dependence of the percentage of inward current carried by $\mathrm{Ca}^{2+}$. In a $\mathrm{Ca}^{2+}$-free external solution, simultaneous recordings of DMPP-induced current and intracellular $\mathrm{Ca}^{2+}$ are shown for a chromaffin cell $(A)$ and $\mathrm{BC} 3 \mathrm{H} 1$ cell $(B)$. The cells were perfused with the impermeant internal solution and held at $-50 \mathrm{mV}$. Cells did not give fura-2 responses in the absence of external $\mathrm{Ca}^{2+} . C$, The percentage of inward current carried by $\mathrm{Ca}^{2+}$ is plotted against the external concentration of $\mathrm{Ca}^{2+}$ for muscle nAChRs (O) and neuronal nAChRs $(\nabla)$. The solid line connects the three theoretical predictions of an ion permeation model for the muscle nAChR (Dani, 1986; Decker and Dani, 1990).

$\alpha$-BGT-sensitive component was contributing to our results. Chromaffin cells showed no evidence for a subpopulation of neuronal nAChRs with a dramatically different $\mathrm{Ca}^{2+}$ permeability.

\section{Permeation models of the $n A C h R$ and the relative permeability of $\mathrm{Ca}^{2+}$ to $\mathrm{Na}^{+}$or $\mathrm{Cs}^{+}$}

Although the permeability ratio of $\mathrm{Ca}^{2}+$ to $\mathrm{Na}{ }^{1}$ or $\mathrm{Cs}^{+}$does not tell the amount of $\mathrm{Ca}^{2+}$ moving through a channel, the ratio can be used to rank the relative $\mathrm{Ca}^{2+}$ permeability of the three major categories of $\mathrm{nAChRs}$. Based on permeability ratio estimates, muscle $\mathrm{nAChRs}$ have a small, but significant, $\mathrm{Ca}^{2+}$ permeability $\left(P_{\mathrm{Ca}} / P_{\mathrm{Na}}\right.$ or $P_{\mathrm{Ca}} / P_{\mathrm{Cs}} \approx 0.2$; Adams et al., 1980; Decker and Dani, 1990; Vernino et al., 1992). Neuronal nAChRs have a greater $\mathrm{Ca}^{2+}$ permeability. Ganglionic nAChRs have a $P_{\mathrm{Ca}} / P_{\mathrm{Na}}$ or $P_{\mathrm{Ca}} /$ $P_{\mathrm{Cs}}$ of about 1.5 (Fieber and Adams, 1991; Sands and Barish, 1991; Vernino et al., 1992), and $\alpha$-BGT-sensitive nAChRs composed of the neuronal $\alpha 7$ subunit have an even greater $\mathrm{Ca}^{2+}$ permeability $\left(P_{\mathrm{Ca}} / P_{\mathrm{Na}} \approx 20\right.$; Séguéla et al., 1993).

These permeability ratio determinations were made by eval- 


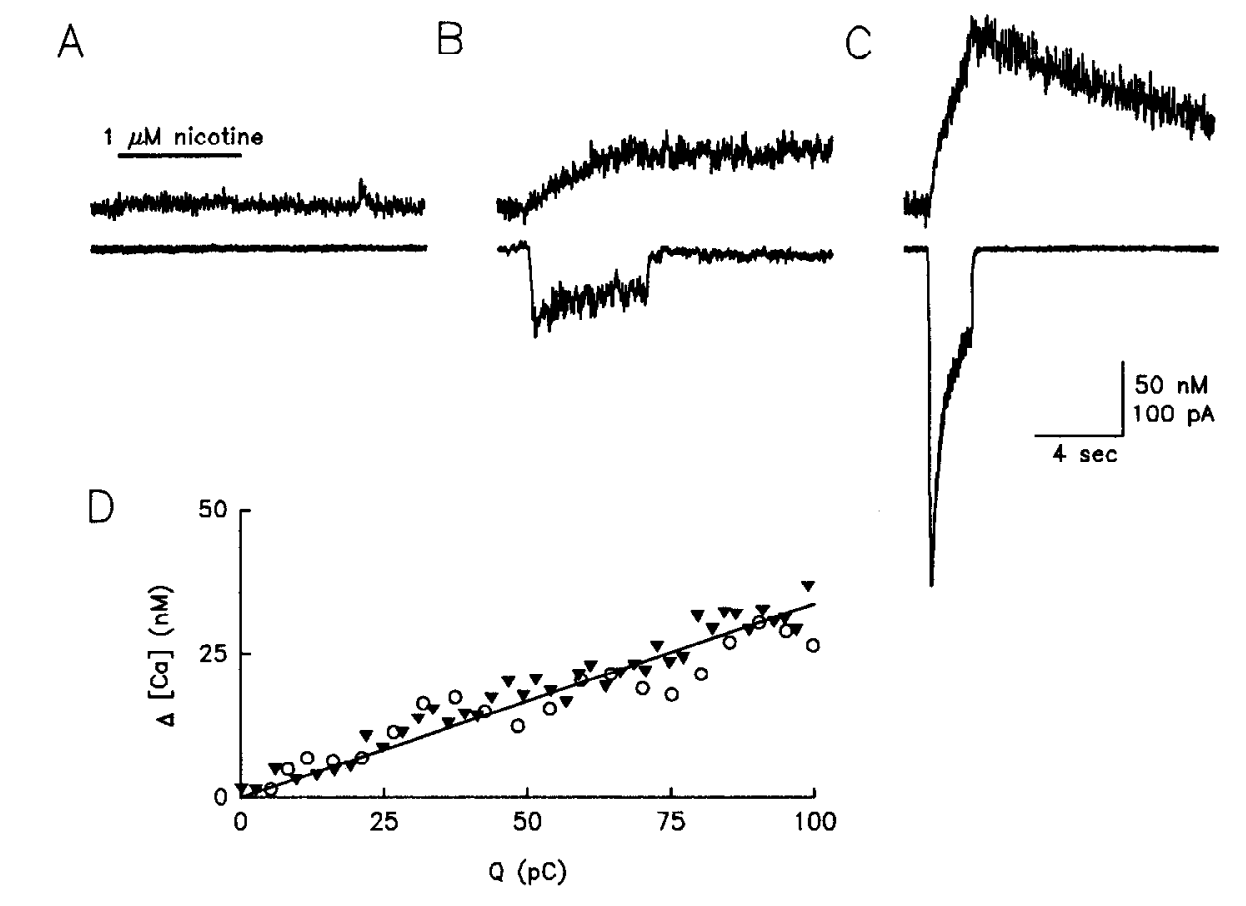

Figure 8. Calcium influx through nicotine-activated channels. Simultaneous recordings of $\mathrm{nAChR}$ current and intracellular $\mathrm{Ca}^{2+}$ were made in chromaffin cells perfused with $\mathrm{Cs}^{+}$and held at $-50 \mathrm{mV}$. A) Application of $1 \mu \mathrm{M}$ nicotine (horizontal bar) failed to induce a membrane current or an intracellular $\mathrm{Ca}^{2+}$ response, but $25 \mu \mathrm{M}$ DMPP induced both responses in all cells tested. $B$, In a different chromaffin cell, 5 response. $C$, In that same cell, $25 \mu \mathrm{M}$ DMPP induced a current and fura- 2 response. $D$, The change in intracellular $\mathrm{Ca}^{2+}$ is plotted against the cationic influx for the recordings in $B$ and $C$. The $\Delta[\mathrm{Ca}]-Q$ relationships are the same for $5 \mu \mathrm{M}$ nicotine ( $\nabla$ ) and for $25 \mu \mathrm{M}$ DMPP $(\mathrm{O})$, and a single linear regression line is drawn through the data. The calibration line in pure external $\mathrm{Ca}^{2+}$ is not shown to simplify the graph. $\mu \mathrm{M}$ nicotine induced a current and fura-2

uating the $\mathrm{Ca}^{2+}$-dependent shift in the reversal potential using the Goldman-Hodgkin-Katz (GHK) equations. It is known, however, that the model of ion permeation represented by the GHK equations does not accurately describe the nAChRs (Lewis, 1979; Adams et al., 1981; Dwyer and Farley, 1984; Sánchez et al., 1986; Dani and Eisenman, 1987). In fact, the GHK model does not describe large data sets of ion permeation for any ion channel that has been studied because the model does not allow for ion binding within the pore (reviews: Hille, 1975, 1992; Levitt, 1986). Therefore, a permeability ratio does not predict the ratio of ion fluxes. For a single occupancy channel like the nAChR, permeability ratios depend only on the energy barriers the ions encounter during permeation, but conductance depends on barriers and binding sites (Hille, 1975; Dani, 1989). Therefore, the GHK permeability ratios are not expected to predict the $\mathrm{Ca}^{2+}$ flux through the nAChR channels. This shortcoming is exemplified by the permeability ratio prediction that the fraction of current carried by $\mathrm{Ca}^{2+}$ should be about sevenfold greater for the neuronal $n A C h R$ than for the muscle $n A C h R$, but our direct measurements show there is only a twofold difference.

A simple, but more realistic, model of ion permeation (Dani, 1986) accurately predicted that $2 \%$ of the current through muscle nAChRs is carried by $\mathrm{Ca}^{2+}$ (Decker and Dani, 1990). The model extends the rate theory approach to consider the basic structure of the pore and is constrained by data so that the narrow region of the pore contains not more than one permeant cation at a time (Dani, 1989). When all of the adjustable parameters of the model are constrained by previous permeation data (Dani and Eisenman, 1987; Dani, 1989; Decker and Dani, 1990), the model reasonably describes the concentration dependence of $\mathrm{Ca}^{2+}$ flux through the muscle nAChR (see Fig. $7 C$ ). In the solution containing $5 \mathrm{mM} \mathrm{Ca}^{2+}$, the model predicts that $3.8 \%$ of the current is carried by $\mathrm{Ca}^{2+}$ compared with the measurement of $3.4 \%$. In addition, the model agrees exactly with the data in predicting that the percentage of current carried by $\mathrm{Ca}^{2+}$ is $2.0 \%$ for inward current and $2.3 \%$ for net current under our experimental conditions. Although the model is not based on or con- strained by the neuronal nAChR, the qualitative features of the data are described. When considering only inward flux, the percentage of current carried by $\mathrm{Ca}^{2+}$ decreases as the potential is depolarized toward 0 . Under physiologic conditions, as the potential approaches $0 \mathrm{mV}$ the percentage of net current carried by $\mathrm{Ca}^{2+}$ increases. Both of these predictions of the model are seen in the data. The model is successful at predicting biologically important aspects of permeation, but it is not intended to precisely describe the molecular details of the permeation process (review: Dani and Levitt, 1990). This success, however, suggests that the permeation model could be valuable if used to develop a model synapse with realistic nAChR channels.

\section{Calcium signals at nicotinic cholinergic synapses}

At the neuromuscular endplate, $\mathrm{Ca}^{2+}$ modulates nAChR synthesis (McManaman et al., 1981; Berlin et al., 1990), nAChR turnover (Rotzler et al., 1991), and nAChR clustering (Bloch and Steinbach, 1981). In addition, $\mathrm{Ca}^{2+}$ may participate in second messenger systems that alter protein phosphorylation (review: Nestler and Greengard, 1984), which in turn may directly modulate nAChRs (reviews: Huganir, 1988; Berg et al., 1989). Calcium influx at the endplate can also have detrimental effects. Agonist-induced myopathy, a necrosis of muscle tissue caused by the absence of AChE or by exogenous agonist application, seems to result from persistent activation of $\mathrm{Ca}^{2+}$-dependent proteases. This myopathy can be prevented by blocking muscle nAChRs or by removing external $\mathrm{Ca}^{2+}$ (Leonard and Salpeter, 1979).

The role of $\mathrm{Ca}^{2+}$ influx at neuronal nicotinic synapses could be even more important and varied. Neuronal nAChRs have both a presynaptic and postsynaptic location. A function of these receptors is to modulate the excitability of neurons (Brown et al., 1984; McCormick and Prince, 1987). Calcium influx is well suited to participate in this modulatory role. Stimulation of presynaptic neuronal nAChRs potentiates the spontaneous and evoked release of neurotransmitters from intact neuronal tissue (Sakurai et al., 1982; Lapchak et al., 1989; review: Wonnacott 
et al., 1990) and from synaptosomes (Belleroche and Bradford, 1978; Rowell and Winkler, 1984). At the neuromuscular junction, neuronal nicotinic autoreceptors on the motoneuron terminal facilitatc the release of ACh and may act to prevent synaptic fatigue (Vizi and Somogyi, 1989; review: Bowman et al., 1990). $\mathrm{Ca}^{2+}$ influx through neuronal nAChRs may participate in some of these presynaptic effects.

The $\mathrm{Ca}^{2+}$ influx through neuronal nAChRs also could participate in activity-dependent plasticity in ways previously reserved for glutamatergic synapses. For example, Messing et al., (1989) showed that activation of neuronal nAChRs in PC12 cells caused the $\mathrm{Ca}^{2+}$-dependent translocation of protein kinase C. It also has been shown that $\mathrm{Ca}^{2+}$ influx through neuronal nAChRs can activate $\mathrm{Ca}^{2+}$-dependent $\mathrm{K}^{+}$and $\mathrm{Cl}^{-}$channels (Tokimasa and North, 1984; Mulle et al., 1992a; Vernino et al., 1992). In septal neurons and in outer hair cells, this secondary activation of $\mathrm{Ca}^{2+}$-dependent channels produces an overall inhibition (Wong and Gallagher, 1991; Fuchs and Morrow, 1992).

The dimensions of the extracellular space between cells at synapses are very small. Therefore, channel activity that allows $\mathrm{Ca}^{2+}$ influx causes a local reduction in extracellular $\mathrm{Ca}^{2+}$ that has been reported throughout the brain (review: Heinemann et al., 1990). A further complexity of the neuronal nicotinic system is that neuronal $\mathrm{nAChRs}$ are modulated by physiological changes in extracellular $\mathrm{Ca}^{2+}$ (Amador et al., 1991; Mulle et al., 1992b; Vernino et al., 1992). $\mathrm{Ca}^{2+}$ influx at neuronal nicotinic synapses could diminish extracellular $\mathrm{Ca}^{2+}$, which would directly inhibit further neuronal nAChR activity. It seems likely that an interplay exists between intracellular and extracellular $\mathrm{Ca}^{2+}$ signals generated by nicotinic synaptic activity and $\mathrm{Ca}^{2+}$-dependent modulation of neuronal nAChRs.

\section{References}

Adams DJ, Dwyer TM, Hille B (1980) The permeability of endplate channels to monovalent and divalent metal cations. J Gen Physiol 75:493-510.

Adams DJ, Nonner W, Dwyer TM, Hille B (1981) Block of endplate channels by permeant cations in frog skeletal muscle. J Gen Physiol 78:593-615.

Akaike A, Mine Y, Sasa M, Takaori S (1990) Voltage and current clamp studies of muscarinic and nicotinic excitation of the rat adrenal chromaffin cells. J Pharmacol Exp Ther 255:333-339.

Alkondon M, Albuquerque EX (1991) Initial characterization of the nicotinic acetylcholine receptors in rat hippocampal neurons. J Recept Res 11:1001-1021.

Amador M, Dani JA (1991) MK-801 inhibition of nicotinic acetylcholine receptor channels. Synapse 7:207-215.

Amador M, Vernino S, Luetje C, Patrick J, Dani JA (1991) Modulation of neuronal nicotinic acetylcholine receptors by calcium. Soc Neurosci Abstr 17:960.

Ascher P, Large WA, Rang HP (1979) Studies on the mechanism of action of acetylcholine antagonists on rat parasympathetic ganglion cells. J Physiol (Lond) 295:139.

Belleroche J, Bradford HF (1978) Biochemical evidence for the presence of presynaptic receptors on dopaminergic nerve terminals. Brain Res 142:53-68.

Berg DK, Boyd RT, Halvorsen SW, Higgins LS, Jacob MH, Margiotta JF (1989) Regulating the number and function of neuronal acetylcholine receptors. Trends Neurosci 12:16-21.

Berlin JR, Wozniak MA, Cannell MB, Bloch RJ, Lederer WJ (1990) Measurement of intracellular $\mathrm{Ca}^{2+}$ in $\mathrm{BC} 3 \mathrm{H}-1$ muscle cells with fura2: relationship to acetylcholine receptor synthesis. Cell Calcium 11: 371-384.

Bloch RJ, Stcinbach JH (1981) Reversible loss of acctylcholine receptor clusters at the developing rat neuromuscular junction. Dev Biol 81:386-391.

Boulter J, Connolly J, Deneris ES, Goldman D, Heinemann S, Patrick J (1987) Functional expression of two neuronal nicotinic acetyl- choline receptors from cDNA clones identifies a gene family. Proc Natl Acad Sci USA 84:7763-7767.

Bowman WC, Prior C, Marshall IG (1990) Presynaptic receptors in the neuromuscular junction. Ann NY Acad Sci 603:69-81.

Brown DA, Docherty RJ, Halliwell JV (1984) The action of cholinomimetic substances on impulse conduction in the habenulointerpeduncular pathway of the rat. J Physiol (Lond) 353:101-109.

Carbonetto ST, Fambrough DM, Muller KJ (1978) Nonequivalence of $\alpha$-bungarotoxin receptors and acetylcholine receptors in chick sympathetic neurons. Proc Natl Acad Sci USA 75:1016-1020.

Clarke PS, Schwartz RD, Paul SM, Pert CB, Pert A (1985) Nicotinic binding in rat brain: autoradiographic comparison of ${ }^{3} \mathrm{H}$-acetylcholine, ${ }^{3} \mathrm{H}$-nicotine, and ${ }^{125} \mathrm{I}$ - $\alpha$-bungarotoxin. $J$ Neurosci 5:1307-1315.

Conti-Tronconi BA, Dunn SMJ, Barnard EA, Dolly OJ, Lai FA, Ray $\mathrm{N}$, Raftery MA (1985) Brain and muscie nicotinic acetylcholine receptors are different but homologous proteins. Proc Natl Acad Sci USA 82:5208-5212.

Couturier S, Bertrand D, Matter J-M, Hernandez M-C, Bertrand S, Millar N, Valera S, Barkas T, Ballivet M (1990) A neuronal nicotinic acetylcholine receptor subunit $(\alpha 7)$ is developmentally regulated and forms a homo-oligomeric channel blocked by $\alpha$-bungarotoxin. Neuron 5:847-856.

Criado M, Alamo L, Navarro A (1992) Primary structure of an agonist binding subunit of the nicotinic acetylcholine receptor from bovine adrenal chromaffin cells. Neurochem Res 17:281-287.

Dani JA (1986) Ion-channel entrances influence permeation. Net charge, size, shape, and binding considerations. Biophys $J$ 49:607-618.

Dani JA (1989) Open channel structure and ion binding sites of the nicotinic acetylcholine receptor channel. J Neurosci 9:882-890.

Dani JA, Eiscnman G (1987) Monovalent and divalent cation permeation in acetylcholine receptor channels: ion transport related to structure. J Gen Physiol 89:959-983.

Dani JA, Levitt DG (1990) Diffusion and kinetic approaches to describe permeation in ion channels. J Theor Biol 146:289-301.

Decker ER, Dani JA (1990) Calcium permeability of the nicotinic acetylcholine receptor: the single-channel calcium influx is significant. J Neurosci 10:3413-3420.

Dwyer TM, Farley JM (1984) Permeability properties of chick myotube acetylcholine-activated channels. Biophys J 45:529-539.

Fabiato A (1988) Computer programs for calculating total from specified free or free from specified total ionic concentrations in aqueous solutions containing multiple metals and ligands. Methods Enzymol 157:378-417.

Fenwick EM, Marty A, Neher E, Sakmann B, Sigworth FJ (1982) Sodium and calcium channels in bovine chromaffin cells. J Physiol (Lond) 331:599-635.

Fieber LA, Adams DJ (1991) Acetylcholine-evoked currents in cultured neurones dissociated from rat parasympathetic cardiac ganglia. J Physiol (Lond) 434:215-237.

Fuchs PA, Murrow BW (1992) Cholinergic inhibition of short (outer) hair cells of the chick's cochlea. J Neurosci 12:800-809.

Grynkiewicz G, Poenie M, Tsien RY (1985) A new generation of $\mathrm{Ca}^{2+}$ indicators with greatly improved fluorescence properties. J Biol Chem 260:3440-3450.

Hamill OP, Marty A, Neher E, Sakmann B, Sigworth FJ (1981) Improved patch-clamp techniques for high-resolution current recordings from cells and cell-free membrane patches. Pfluegers Arch 391:85100.

Heinemann U, Stabel J, Rausche G (1990) Activity-dependent ionic changes and neuronal plasticity in rat hippocampus. Prog Brain Res 83:197-214.

Hille B (1975) Ionic selectivity of $\mathrm{Na}$ and $\mathrm{K}$ channels of nerve membranes. In: Membranes-a series of advances, Vol 3, Lipid bilayers and biological membranes: dynamic properties (G Eisenman, ed), pp 255-323. New York: Dekker.

Hille B (1992) Ionic channels in excitable membranes. Sunderland, MA: Sinauer

Huganir RL (1988) Regulation of the nicotinic acetylcholine receptor channel by protein phosphorylation. Curr Top Membr Transpl 33: 147-163.

Hussy N, Bertrand D (1991) Single channel currents through $\alpha$-bungarotoxin-sensitive neuronal nicotinic acetylcholine receptors. Soc Neurosci Abstr 17:249.

Jacob MH, Berg DK (1983) The uitrastructural localization of $\alpha$-bungarotoxin binding sites in relation to synapses on chick ciliary ganglion neurons. J Neurosci 3:260-271. 
Katz B, Miledi R (1969) Spontaneous and evoked activity of motor nerve endings in calcium ringer. $J$ Physiol (Lond) 203:689-706.

Lapchak PA, Araujo DM, Quirion R, Collier B (1989) Presynaptic mechanisms in the rat cerebellum: evidence for nicotinic, but not muscarinic autorcceptors. J Neurochem 53:1843-1851.

Leonard JP, Salpeter MM (1979) Agonist-induced myopathy at the neuromuscular junction is mediated by calcium. J Cell Biol 82:811819.

Levitt DG (1986) Interpretation of biological ion channel flux data: reaction-rate versus continuum theory. Annu Rev Biophys Biophys Chem 15:29-57.

Lewis CA (1979) lon-concentration dependence of the reversal potential and the single channel conductance of ion channels at the frog neuromuscular junction. J Physiol (Lond) 286:417-455.

Lipscombe D, Madison DV, Poenie M, Reuter H, Tsien RW, Tsien RY (1988) Imaging of cytosolic $\mathrm{Ca}^{2+}$ transients arising from $\mathrm{Ca}^{2+}$ stores and $\mathrm{Ca}^{2+}$ channels in sympathetic neurons. Neuron 1:355-365.

Lipton SA, Aizenman E, Loring RH (1987) Neural nicotinic acetylcholine responses in solitary mammalian retinal ganglion cells. Pfluegers Arch 410:37-43.

Luetje CW, Patrick J (1991) Both alpha and beta subunits contribute to the agonist sensitivity of neuronal nicotinic acetylcholine receptors. J Neurosci 11:837-845.

Luetje CW, Wada K, Rogers S, Abramson SN, Tsuji K, Heinemann S, Patrick J (1990) Neurotoxins distinguish between different neuronal nicotinic acetylcholine receptor subunit combinations. J Neurochem $55: 632-640$.

Malgaroli A, Fesce R, Meldolesi J (1990) Spontaneous $\left[\mathrm{Ca}^{2+}\right]_{i}$ fluctuations in rat chromaffin cells do not require inositol 1,4,5-trisphosphate elevations but are generated by a caffeine- and ryanodinesensitive intracellular $\mathrm{Ca}^{2+}$ store. J Biol Chem 265:3005-3012.

Mathie A, Cull-Candy SG, Colquhoun D (1987) Single-channel and whole-cell currents evoked by acctylcholine in dissociated sympathetic neurons of the rat. Proc R Soc Lond [Biol] 232:239-248.

McCormick DA, Prince DA (1987) Acetylcholine causes rapid nicotinic excitation in the medial habenular nucleus of guinea pig, in vitro. J Neurosci 7:742-752.

McManaman JL, Blosser JC, Appel SH (1981) The effect of calcium of acetylcholine receptor synthesis. J Neurosci 1:771-776.

Messing RO, Stevens AM, Kiyasu E, Sneade AB (1989) Nicotinic and muscarinic agonists stimulate rapid protein kinase $\mathrm{C}$ translocation in PC1 2 cells. J Neurosci 9:507-512.

Moss BL, Schuetze SM, Role LW (1989) Functional properties and developmental regulation of nicotinic acetylcholine receptors on embryonic chicken sympathetic neurons. Neuron 3:597-607.

Mulle C, Changeux JP (1990) A novel type of nicotinic receptor in the rat central nervous system characterized by patch-clamp techniques. J Neurosci 10:169-175.

Mulle C, Choquet D, Korn H, Changeux JP (1992a) Calcium influx through nicotinic receptor in rat central neurons: its relevance to cellular regulation. Neuron $8: 135-143$.

Mulle C, Lena C, Changeux JP (1992b) Potentiation of nicotinic receptor response by external calcium in rat central neurons. Neuron 8:937-945.

Nestler EJ, Greengard P, eds (1984) Protein phosphorylation in the nervous system. New York: Wiley.

Papke RL, Boulter J, Patrick J, Heinemann S (1989) Single-channel currents of rat neuronal nicotinic acetylcholine receptors expressed in Xenopus oocytes. Neuron 3:589-596.

Rotzler S, Schramek H, Brenner HR (1991) Metabolic stabilization of endplate acetylcholine receptors regulated by $\mathrm{Ca}^{2+}$ influx associated with muscle activity. Nature 349:337-339.

Rowell PP, Winkler DL (1984) Nicotinic stimulation of ${ }^{3} \mathrm{H}$-acetylcholine release from mouse cerebral cortical synaptosomes. J Neurochem 43:1593-1598.

Sakurai Y, Takano Y, Kohjimoto Y, Honda K, Kamiya H-O (1982)
Enhancement of $\left[{ }^{3} \mathrm{H}\right]$ dopamine release and its $\left[{ }^{3} \mathrm{H}\right]$ metabolites in rat striatum by nicotinic drugs. Brain Res 242:99-106.

Sánchez JA, Dani JA, Siemen D, Hille B (1986) Slow permeation of organic cations in acetylcholine receptor channels. J Gen Physiol 87 : 985-1001.

Sands SB, Barish ME (1991) Calcium permeability of neuronal nicotinic acetylcholine receptor channels in PC-12 cells. Brain Res 560: $38-42$.

Sargent P (1993) The diversity of neuronal nicotinic acetylcholine receptors. Annu Rev Neurosci 16:403-443.

Schneggenburger R, Zhou Z, Konnerth A, Neher, E (1993) Fractional contribution of calcium to the cation current through glutamate receptor channels. Neuron 11:133-143.

Schoepfer R, Conroy W, Whiting P, Gore M, Lindstrom J (1990) Brain $\alpha$-bungarotoxin binding protein cDNAs and mAbs reveal subtypes of this branch of the ligand-gated ion channel gen superfamily. Neuron $5: 35-48$.

Schulz DW, Loring RH, Aizenman E, Zigmond RE (1991) Autoradiographic localization of putative nicotinic receptors in the rat brain using ${ }^{125}$ I-neuronal bungarotoxin. J Neurosci 11:287-297.

Séguéla P, Wadiche J, Dineley-Miller K, Dani JA, Patrick JW (1993) Molecular cloning, functional expression and distribution of rat brain $\alpha 7$ : a nicotinic cation channel highly permeable to calcium. J Neurosci 13:596-604.

Thayer SA, Miller RJ (1990) Regulation of the intracellular free calcium concentration in single rat dorsal root ganglion neurones in vitro. J Physiol (Lond) 425:85-115.

Thayer SA, Hirning LD, Miller RJ (1988a) The role of caffeine-sensitive calcium stores in the regulation of the intracellular free calcium concentration in rat sympathetic neurons in vitro. Mol Pharmacol 34: 664-673.

Thayer SA, Sturek M, Miller RJ (1988b) Measurement of neuronal $\mathrm{Ca}^{2+}$ transients using simultancous microfluorimetry and clectrophysiology. J Physiol (Lond) 412:216-223.

Tokimasa T, North RA (1984) Calcium entry through acetylcholine channels can activate potassium conductance in bullfrog sympathetic neurons. Brain Res 295:364-367.

Trouslard J, Marsh SJ, Brown DA (1993) Calcium entry through nicotinic receptor channels and calcium channels in cultured rat superior cervical ganglion cells. J Physiol (Lond) 468:53-71.

Vernino S, Amador M, Luetje CW, Patrick J, Dani JA (1992) Calcium modulation and high calcium permeability of neuronal nicotinic acetylcholine receptors. Neuron 8:127-135.

Vijayaraghavan S, Pugh PC, Zhang Z, Rathouz MM, Berg DK (1992) Nicotinic receptors that bind $\alpha$-bungarotoxin on neurons raise intracellular free calcium. Neuron 8:353-362.

Vizi ES, Somogyi GT (1989) Prejunctional modulation of acetylcholine release from the skeletal neuromuscular junction: link between positive (nicotinic)- and negative (muscarinic)-feedback mechanisms. Br J Pharmacol 97:65-70.

Wong LS, Gallagher JP (1991) Pharmacology of nicotinic receptormediated inhibition in rat dorsolateral septal neurones. J Physiol (Lond) 436:325-346.

Wonnacott S, Drasdo A, Sanderson E, Rowell P (1990) Presynaptic nicotinic receptors and the modulation of transmitter release. In: The Biology of nicotine dependence (Bock G, Marsh J, eds), pp 87-105. New York: Wiley.

Thang Z-w, Vijayaraghavan S, Berg DK (1994) Neuronal acetylcholine receptors that bind $\alpha$-bungarotoxin with high affinity function as ligand-gated ion channels. Neuron 12:167-177.

Zhou Z, Neher E (1993) Calcium permeability of nicotinic acetylcholine receptor channels in bovine adrenal chromaffin cells. Pfluegers Arch 425:511-517.

Zorumski CF, Thio LL, Isenberg KE, Clifford DB (1992) Nicotinic acetylcholine currents in cultured postnatal rat hippocampal neurons. Mol Pharmacol 41:931-936. 